\title{
3D GRAVITY MODELING OF IMPACT STRUCTURES IN BASALTIC FORMATIONS IN BRAZIL: PART II - VISTA ALEGRE, PARANÁ
}

\author{
Júlio César Ferreira ${ }^{1}$, Emilson Pereira Leite², \\ Marcos Alberto Rodrigues Vasconcelos ${ }^{3}$ and Alvaro Penteado Crósta ${ }^{2}$
}

\begin{abstract}
This study characterized the subsurface framework of the Vista Alegre impact structure in terms of a 3D mass density model obtained from forward gravity modeling, constrained by petrophysical and geological data from a previously published work. Like the nearby Vargeão impact structure, Vista Alegre is a complex impact structure formed in basaltic lava flows of the Serra Geral Formation with a central uplift exposing sandstones of Piramboia/Botucatu Formations and impact breccias. A 3D mass density model is proposed, consisting of five subsurface layers: polymictic breccias, shocked/fractured basalts, basalts (Serra Geral), shocked sandstones (Piramboia/Botucatu) and a lower layer of pre-Triassic sedimentary rocks. The central region containing the fractured polymictic breccias and shocked target rocks (basalt and sandstone) is $\sim 100 \mathrm{~m}$ thick. The target rocks are deformed at depths of up to $\sim 1 \mathrm{~km}$, which represents the basal contact of the sandstones of the Piramboia/Botucatu Formations with pre-Triassic strata. Values of structural uplift ( $650 \mathrm{~m})$, central uplift diameter ( $\sim 3.5 \mathrm{~km})$ and depth of excavation $(\sim 400 \mathrm{~m})$ inferred from our model are fairly consistent with theoretical values, thus supporting a meteoritic impact nature. The Vista Alegre model is in agreement with the density model for the nearby Vargeão impact crater and provides new insights into the formation of impact structures in basaltic targets, with potential implications for the study of other planetary surfaces.
\end{abstract}

Keywords: density modeling, impact crater, central uplift, Serra Geral Formation.

RESUMO. Este estudo apresenta uma caracterização em subsuperfície da estrutura de impacto Vista Alegre em termos de um modelo 3D de densidade de massa obtido a partir de uma modelagem direta de dados gravimétricos, vinculada a dados petrofísicos e dados de mapeamento geológico previamente publicados. Assim como a cratera de Vargeão, Vista Alegre é uma estrutura de impacto complexa, formada em fluxos de lava da Formação Serra Geral, com elevação central expondo arenitos das Formações Piramboia/Botucatu e brechas de impacto. Foi proposto um modelo constituído por cinco camadas em subsuperfície: brechas polimíticas, basaltos fraturados, basaltos (Serra Geral), arenitos (Piramboia/Botucatu) e uma camada inferior de rochas pré-Triássicas. A região central contendo as brechas polimíticas e as rochas-alvo fraturadas (basaltos e arenitos) tem $\sim 100 \mathrm{~m}$ de espessura. As rochas da região do impacto estão modificadas até profundidades de $\sim 1 \mathrm{~km}$, onde ocorre 0 contato entre as camadas pré-Triássicas e os arenitos das Formações Piramboia/Botucatu. Valores de soerguimento estrutural ( $\sim 650 \mathrm{~m}$ ), diâmetro do núcleo central soerguido ( 3,5 km) e profundidade de escavação ( $\sim 00 \mathrm{~m}$ ) são consistentes com valores teóricos que podem ser inferidos do nosso modelo, reforçando a origem por impacto meteorítico. Em geral, o modelo de Vista Alegre está de acordo com o modelo de densidades da cratera de impacto de Vargeão e fornece novos conhecimentos sobre a formação de estruturas de impacto em alvos basálticos e para estudos de geologia planetária.

Palavras-chave: modelo de densidades, cratera de impacto, núcleo soerguido, Formação Serra Geral.

\footnotetext{
${ }_{1}^{1}$ Refinaria de Paulínia (Replan). Rodovia SP 332 - Km 130 13147-900 Paulínia, SP, Brazil - E-mail: juliocferr@petrobras.com

${ }^{2}$ Universidade Estadual de Campinas, Instituto de Geociências, Departamento de Geologia e Recursos Naturais, Rua João Pandiá Calógeras, 51 - Cidade Universitária 13083-970 Campinas, SP, Brazil -E-mails: emilson@ige.unicamp.br, alvaro@ige.unicamp.br

${ }^{3}$ Universidade Federal da Bahia, Instituto de Geociências, Departamento de Geofísica, Rua Barão de Jeremoabo, S/N, Campus Universitário de Ondina 40170-290 Salvador, BA, Brazil -E-mail: marcos.vasconcelos@ufba.br
} 


\section{INTRODUCTION}

As mentioned in Part I (Ferreira et al., 2015), our work consisted in a detailed ground gravimetric survey of Vargeão and Vista Alegre impact structures, distant around $100 \mathrm{~km}$ apart in a similar geological context (Fig. 1). Therefore, we divided this work into two parts: Part I presents the results obtained from gravity data acquired at Vargeão impact structure (Ferreira et al., 2015); Part II brings the results obtained for the Vista Alegre impact structure. A general introduction about impact craters, basaltic targets and the application of gravity data for studying them is presented by Ferreira et al. (2015).

Similar to the slightly larger Vargeão impact structure, the Vista Alegre structure is a relatively eroded impact crater, which hampers the direct investigation of its morpho-structural features. In such cases, the application of geophysical methods becomes important to map the distribution of physical properties that can be associated with geological features and structures in subsurface (Pilkington \& Grieve, 1992).

The Vista Alegre structure was the subject of a ground gravimetric survey aiming to generate a subsurface model that delimits the different geological layers and identifies post-impact stratigraphic changes.

In particular, we present a 3D subsurface mass density model of the Vista Alegre impact structure obtained from modeling gravity data. This model was geologically interpreted, depicting basement depth, layers thicknesses and geometrical characteristics of the central uplift.

The Vista Alegre gravity model is compared to that obtained for Vargeão to respond to the specific questions formulated in Part I (Ferreira et al., 2015): "(i) Even though the two structures are relatively close to each other, are they similar in terms of subsurface geology? (ii) Have one of the two impacts affected the subsurface more than the other? (iii) Are the volume and shape of possible uplifted sandstone similar?". It is rather important to notice that the elevation of the center of the Vista Alegre structure is relatively inconspicuous; therefore subsurface models such as the one presented here can disclose the framework of the central uplift.

\section{The Vista Alegre impact structure}

Centered at $25^{\circ} 57^{\prime} \mathrm{S}$ and $52^{\circ} 41^{\prime} \mathrm{W}$, the Vista Alegre structure is located in the county of Coronel Vivida-PR (Fig. 2). The structure was named after the Vista Alegre village, located in the northwestern portion of the structure, in between the center and the rim. It was first described in 2004, with the aid of satellite images, as a circular depression with morphology, structures and deformation that could be the result of a meteorite impact, similar to that of Vargeão impact structure (Crósta et al., 2004). Later studies have found and described the impact evidence necessary to prove the structure as being of impact origin and provided details of its morphology (Crósta et al., 2010).

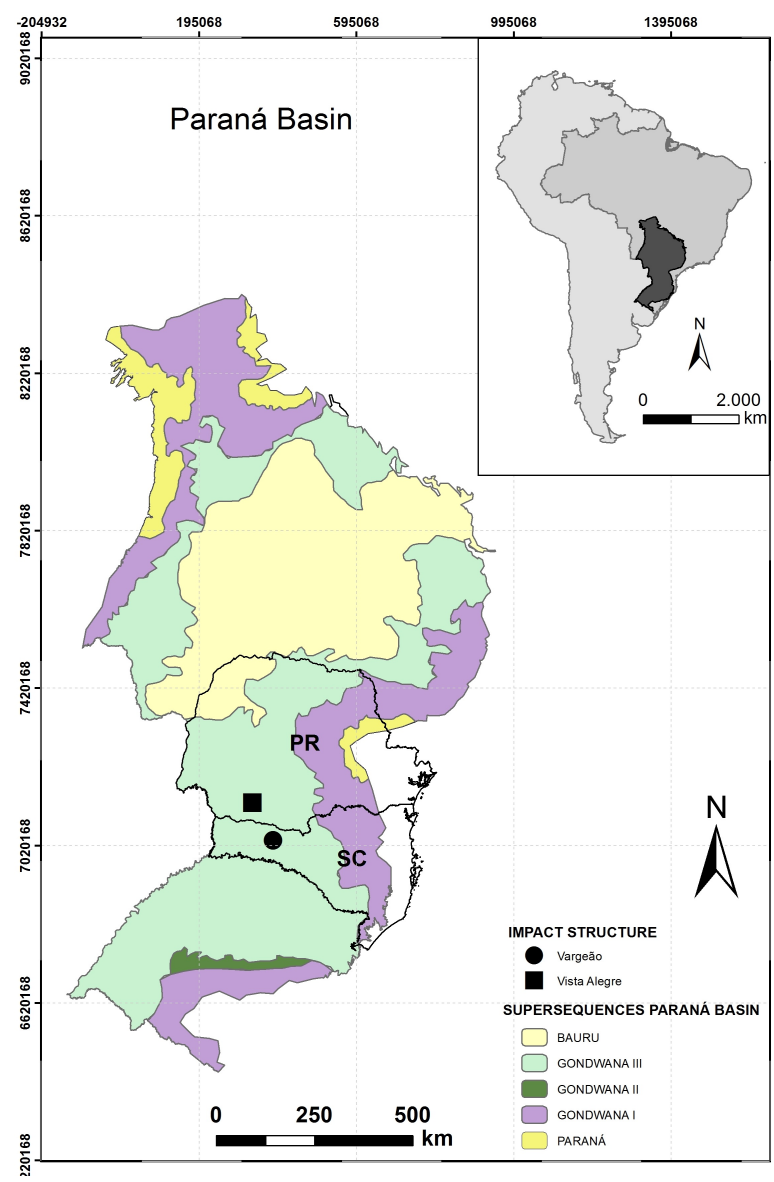

Figure 1 - Geological map of the Paraná Basin (adapted from Milani et al., 1998). Vargeão and Vista Alegre impact structures are located in the states of Santa Catarina and Paraná, respectively. A summary of the regional geology is presented in Part I (Ferreira et al., 2015).

With a diameter of $\sim 9.5 \mathrm{~km}$, it has also been described as a complex impact structure. The presence of subtle topographic elevations (Crósta et al., 2010) and the anomalous presence of sandstones in the central portion of the Piramboia/Botucatu Formations, within a circle of $3 \mathrm{~km}$ diameter, indicate the presence of a central uplift (Crósta, 2012).

Having a circular rim in the form of a ring of escarpments and an internal depression, the structure's boundaries are well delimited with the exception of its south and southwestern edges, which were removed by the erosive action of the Chopin River. 


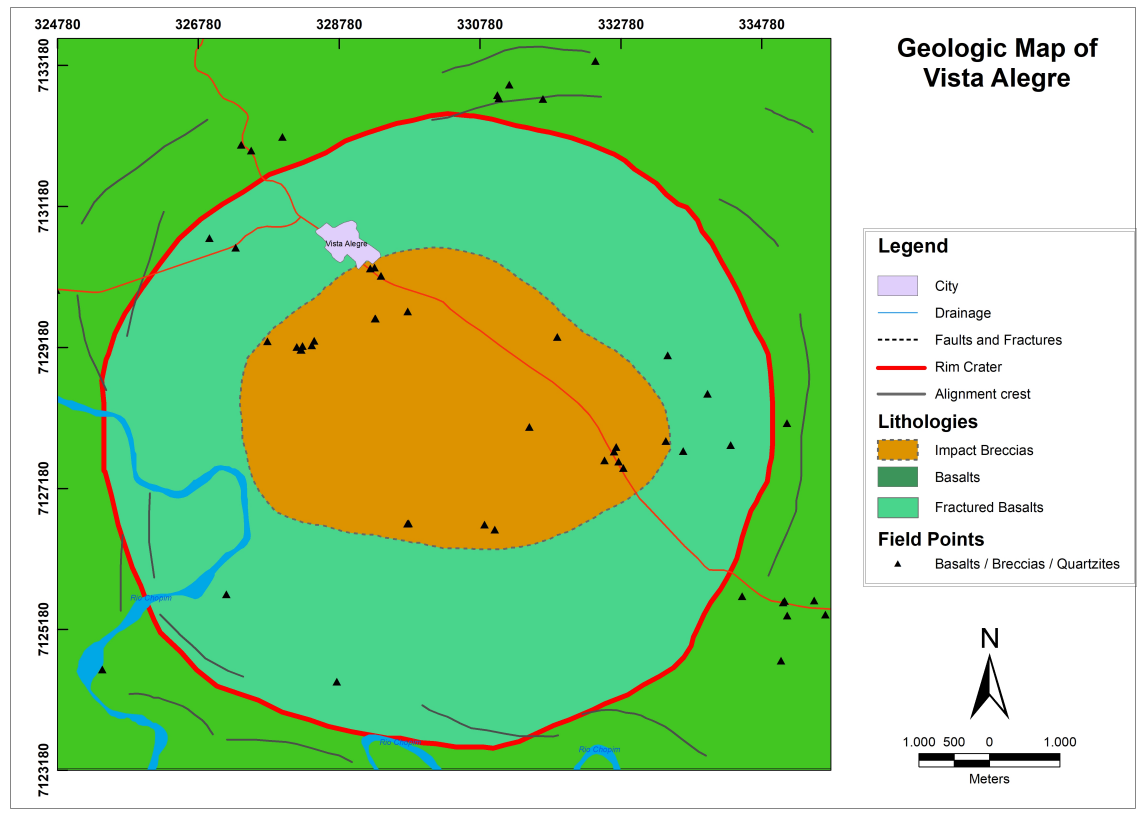

Figure 2 - Generalized geological map of the Vista Alegre impact structure (Furuie, 2006).

An unconstrained maximum age of $125 \mathrm{Ma}$ for the Vista Alegre impact structure can be drawn from the age of the Serra Geral volcanism (Crósta et al., 2013), as the structure was formed on basaltic flows with a Cretaceous age range between 139 and $125 \mathrm{Ma}$ (Turner et al., 1994). Crósta et al. (2010) provided a geological characterization and complete description of Vista Alegre as an impact structure. That study was based on geomorphological analyses conducted on the SRTM digital elevation model and on field geological observations that led to the identification of impact evidence, such as the occurrence of shatter cones and planar deformation features in quartz grains from polymict breccias.

\section{Local Geology}

Crósta et al. (2010) describe the area of the impact crates with basalts and shocked/fractured basalts of the Serra Geral Formation, polymictic impact breccias and sedimentary layers underlying the Serra Geral Formation (Fig. 2). The Serra Geral Formation corresponds to tholeiitic basalts. Fractured basalts are found in an annular area between the rim and the center of the structure. This fracturing is relatively strong and attributed to effects of the impact and later deformation processes of the modification stage of the crater formation (Crósta et al., 2013). The polymictic lithic breccias formed directly by the impact process as a mixture of the target rocks. They occur in a circular area of approximately $20 \mathrm{~km}^{2}$ in the central portion of the structure, forming a continuous layer underlying the soil, with thicknesses ranging from 8 to $12 \mathrm{~m}$, according to inferences based on observations of breccia outcrops presented in Furuie (2006) and Crósta et al. (2013). The sedimentary layers underlying the Serra Geral Formation were not represented because in-situ sandstone outcrops are rarely found. Those rocks are normally located between 700 to $900 \mathrm{~m}$ deep in the region outside the Vista Alegre structure (Furuie, 2006). However, there are small sandstone occurrences around the center of the structure, as lose blocks found mixed with red soils which are a typical product of weathering of the rocks of the Serra Geral Formation. These quartzose rocks were interpreted as being brought to the near surface as a result of uplift of the sedimentary rocks of the Piramboia or Botucatu Formations (Crósta et al., 2013)

\section{METHODOLOGY}

Vista Alegre ground gravimetric data were acquired during a field campaign in 2013 using a CG-5 Scintrex gravimeter along with a Trimble ProXT DGPS for geometrical height measurements. The reader is referred to Part I for details about the resolution and accuracies of those instruments (Ferreira et al., 2015). The survey was carried out mainly along roads covering the entire area of the structure (Fig. 3). Gravity data were collected at 343 locations, 


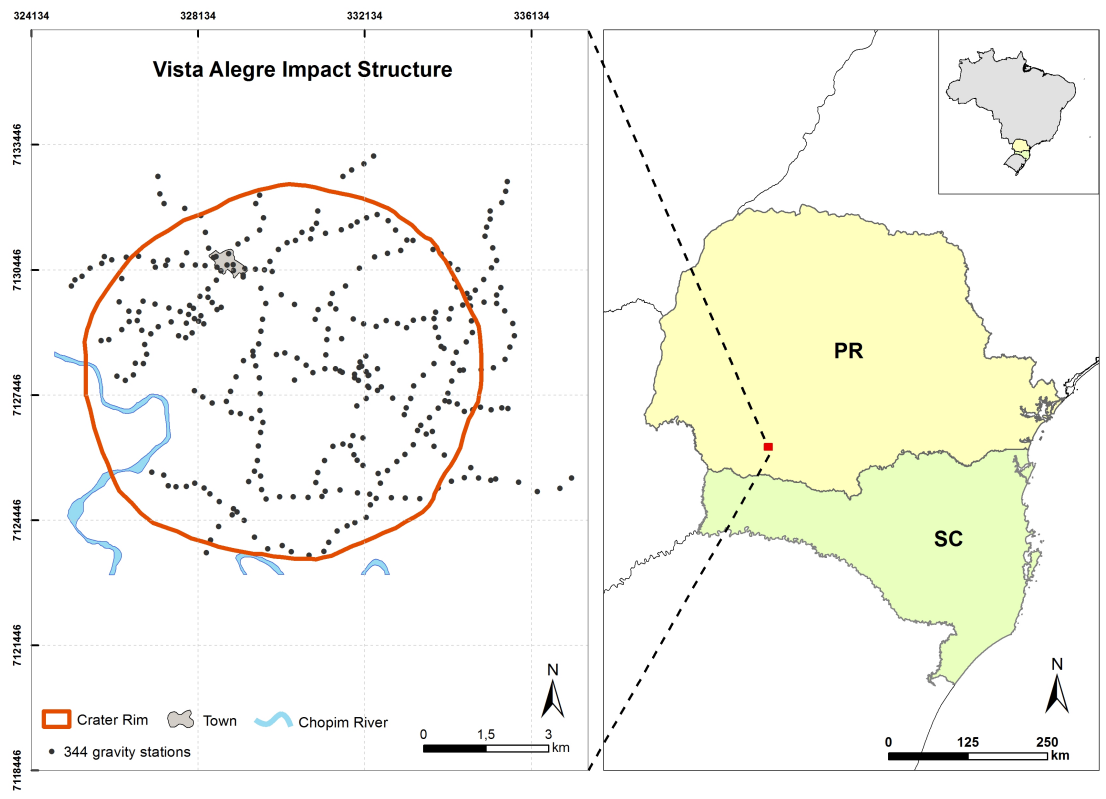

Figure 3 - Spatial distribution of the ground gravimetric stations within and around the Vista Alegre impact structure.

most of them spaced from 200 to $500 \mathrm{~m}$ apart. All data were georeferenced to the WGS 84 Datum and UTM projection in zone $22 \mathrm{~S}$ was applied. A minimum curvature algorithm was used to interpolate the observed data into a regular grid with cells of 50 $\mathrm{m} \times 50 \mathrm{~m}$ (Ferreira et al., 2015). Data were not collected in the southwestern limit of the structure, due the presence of the Rio Chopim (Fig. 3) that prevented access to this region.

\section{Data processing}

We performed a regional-residual separation by fitting a second-degree polynomial surface to the total Bouguer anomaly and subtracting this surface from the total Bouguer anomaly, resulting in the residual Bouguer anomaly. The subsequent modeling was then performed using the residual Bouguer anomaly as observed data. The relevant equations are found in Ferreira et al. (2015).

\section{D gravity forward modeling}

Forward modeling was carried out using GMSYS-3D software, available in Geosoft Oasis Montaj $®$ (Popowski et al., 2006), in the same way as that described in Ferreira et al. (2015). Based on the available geological map, we used the following set of rock layers in our model, from the deepest to the shallowest: (1) Pre-Triassic units; (2) Sandstones of the Piramboia and Botucatu Formations; (3) Basalt; (4) Shocked/fractured basalt; (5) Impact breccias. We used absolute density values measured from rock samples representing each layers to constrain our model. The modeling algorithm discretizes the entire interpretative volume into a mesh with a constant density assigned to each cell. Our model has $217 \times 193 \times 56$ cells along the EW, NS and vertical directions, respectively, each measuring $50 \times 50 \times 20 \mathrm{~m}$.

\section{RESULTS AND DISCUSSIONS}

Total, regional and residual Bouguer anomalies of the Vista Alegre impact structure are depicted in Figure 4. A nearly circular negative anomaly is associated with the center of the structure. That gravity signature can be related to the higher degree of deformation expected to occur at the center of an impact structure (Grieve, 1987). For Vista Alegre, the residual Bouguer anomaly has a minimum value of $-2.5 \mathrm{mGal}$ in its central region (Fig. $4 C)$. Surrounding the center of the crater, the data depict a ring of highly variable amplitudes (from 0.5 to $1.1 \mathrm{mGal}$ ). The Vargeão structure exhibits a similar ring, but completely closed and showing lower values (Ferreira et al., 2015), although not so well defined as in Vista Alegre. Additionally, the Vista Alegre anomaly decreases outwards, so that the crater rim does not show any typical signature.

\section{D density model}

The 3D model (Fig. 5) includes, from bottom to top: a base layer of pre-Triassic rocks, followed by a sandstone layer and a basalt layer. Layers of shocked/fractured basalts and impact breccias 
A)

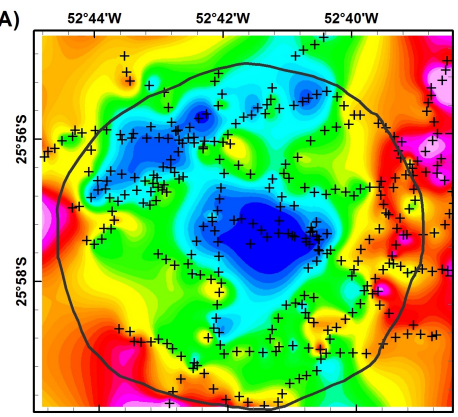

C)

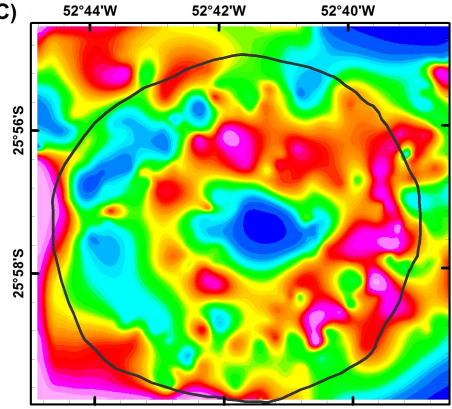

B)
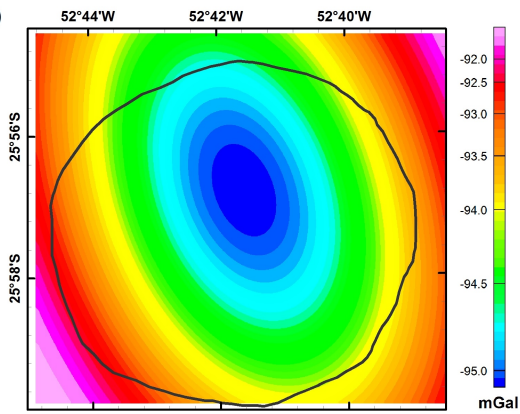

Crater Rim of Vista Alegre

+ Gravity Stations on Land
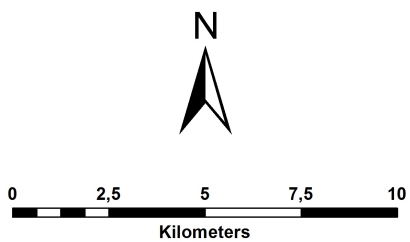

Figure 4 - Bouguer anomalies of the Vista Alegre impact structure. (A) Total gravity anomaly; (B) Regional anomaly; (C) Residual anomaly comprised by the difference between grids of total gravity anomaly and regional anomaly.

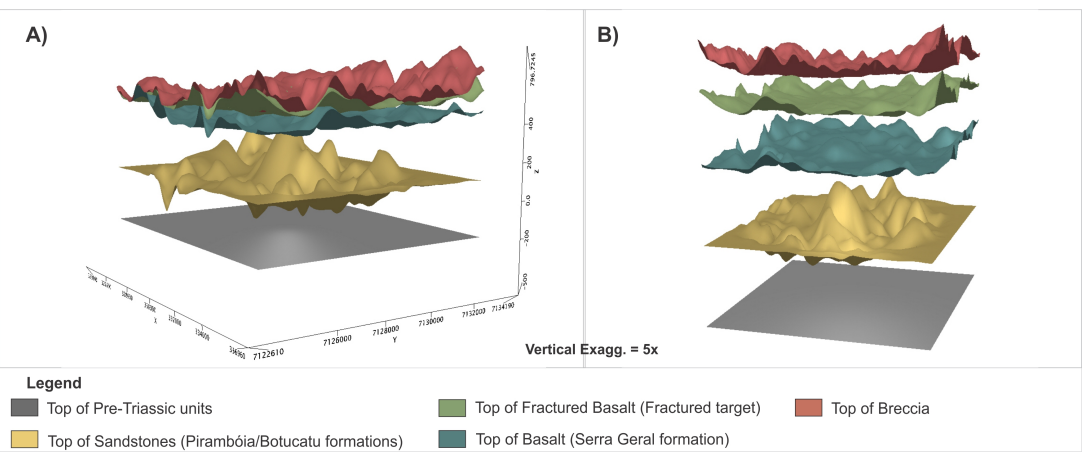

Figure 5 - 3D gravity model of the Vista Alegre impact structure. Density values are shown in Table 1. (A) Subsurface layers without vertical exaggeration of $5 x$. (B) Subsurface layers with a vertical exaggeration of $5 x$.

Table 1 - Densities of rock samples extracted from Vista Alegre.

\begin{tabular}{|l|c|c|c|c|}
\hline \multirow{2}{*}{ Lithology } & \multicolumn{4}{|c|}{ Densities $\left(\mathbf{g} / \mathbf{c m}^{\mathbf{3}}\right.$ ) } \\
\cline { 2 - 5 } & $\min$ & $\max$ & average & SD \\
\hline Sandstones Piramboia / Botucatu & 2.41 & 2.44 & 2.43 & 0.01 \\
\hline Alto Uruguai Basalt & 2.84 & 2.95 & 2.88 & 0.04 \\
\hline Fractured Basalt & 2.66 & 2.82 & 2.74 & 0.06 \\
\hline Impact Breccia & 2.27 & 2.48 & 2.39 & 0.05 \\
\hline
\end{tabular}


are also represented in the upper part of the model, both of them filling the annular cavity of the impact structure. Similarly to the procedure used for Vargeão (Ferreira et al., 2015), the density values shown in Table 1 were defined based on densities measured from real samples by Yokoyama (2013), except for the layer of more acidic volcanic rocks (the Acidic Chapecó unit). These densities were measured using a precision balance and applying the methodology described in Ferreira (2017). The crater rim and the layer thicknesses were defined based on Furuie (2006) and Milani et al., (1998), respectively.

Figure 6 shows the fitting between calculated (forward modeling) and observed anomalies, as well as their histograms. Comparison of the Bouguer residual anomaly map (Fig. 6A) with the modeled field (Fig. 6B) displays consistent spatial distribution and values, which is also reinforced by the information shown in the histograms. As observed in Figure 6C, the mean error is $-0.07 \mathrm{mGal}$ and the standard deviation is $0.42 \mathrm{mGal}$. However, because of interpolation artefacts, higher amplitude errors occur particularly at the edges of the map and in some areas where there are no observation points.

To better interpret the subsurface of the impact structure and the distribution of rock densities, four vertical sections were extracted from the 3D model. The profiles A-A' and B-B' (Fig. 7), and C-C' and D-D' (Fig. 8) were extracted along the N-S, W-E, NW-SE and NE-SW directions. A layer of varying from 500 to
$800 \mathrm{~m}$ thick of Serra Geral basalt is observed superposing rocks of the 300 to $400 \mathrm{~m}$ thick Piramboia/Botucatu Formations. The model depicts a classic shape of a complex impact structure with a 300m uplift of the less dense Piramboia/Botucatu Formation. This uplift is surrounded by two types of rock that are related to the impact: shocked/fractured basalts and polymictic breccias. The top of the pre-Triassic units, at $\sim 700 \mathrm{~m}$ depth, is a good inference of the maximum depth that the impact-related deformation have reached, as the residual field was reduced to satisfying amplitudes without deforming such horizons. Both B-B' and C-C' profiles in (Figs. 7 and 8 ) were used to estimate the crater rim and then to suggest a structure with a diameter of $\sim 9.5 \mathrm{~km}$, agreeing with the crater size defined by Crósta et al. (2004) and Crósta et al. (2010).

Each layer of the model (Fig. 5) was isolated in order to better interpret its 3D shape. The uppermost layers, corresponding to shocked/fractured basalts and impact breccias, have been estimated to be $\sim 100 \mathrm{~m}$ thick (Fig. 9). We observe that breccias have a wide occurrence surrounding the center and in the eastern portion, reaching a maximum thickness of $30 \mathrm{~m}$ and an average of $8.5 \mathrm{~m}$. The works of Furuie (2006) and Crósta et al. (2013) also inferred that the polymorphic breccias have thickness between 8 and $12 \mathrm{~m}$ around the center, which is in accordance with our model. Underneath the shocked/fractured basalt, there is a $\sim 500 \mathrm{~m}$ thick layer of unfractured basalt of the Serra Geral Formation corresponding to the floor of the transient cavity. These
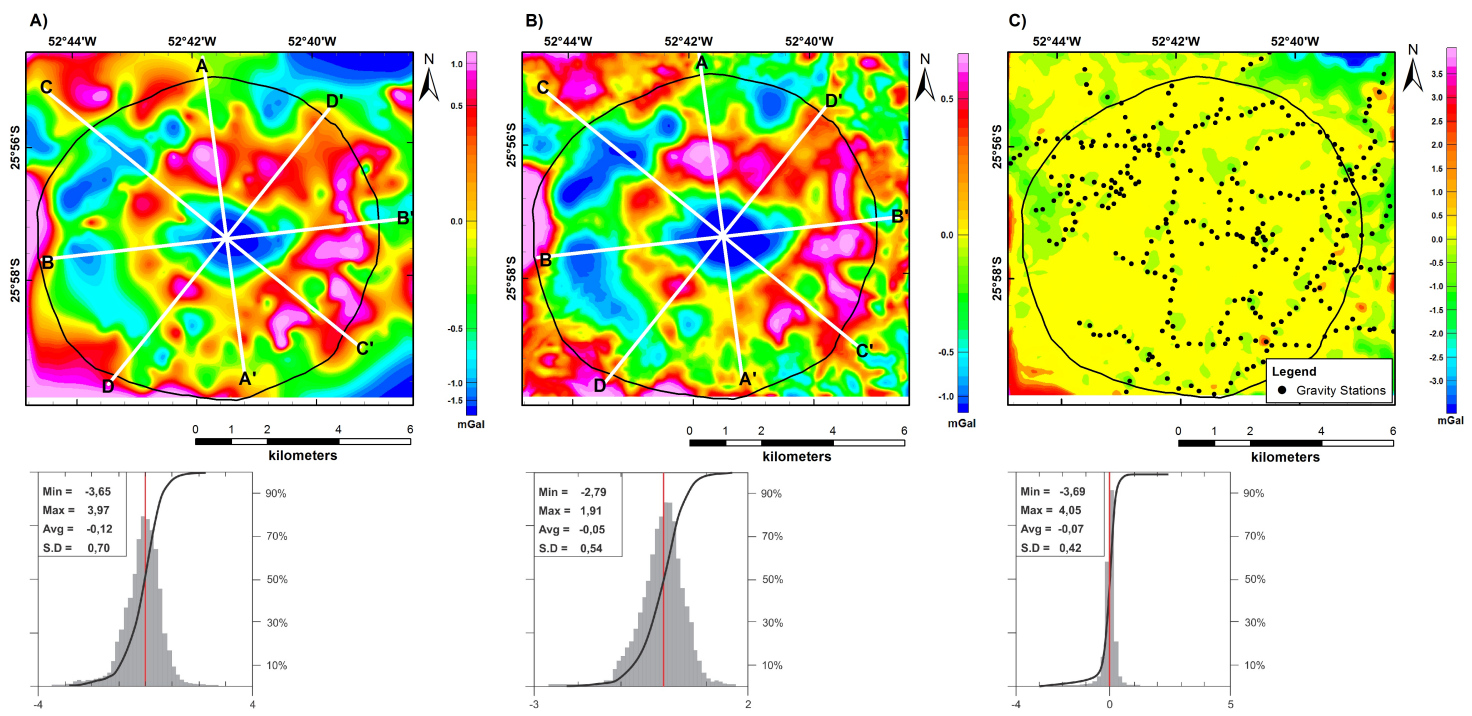

Figure 6 - Comparison among residual Bouguer anomalies. (A) Observed; (B) Calculated from the 3D mass density model; (C) Difference between grids in $A$ and $B$. Data in the corresponding histograms are in $\mathrm{mGal}$. White lines represent positions along which vertical sections were extracted from the model. Solid black lines represent the crater rim. 


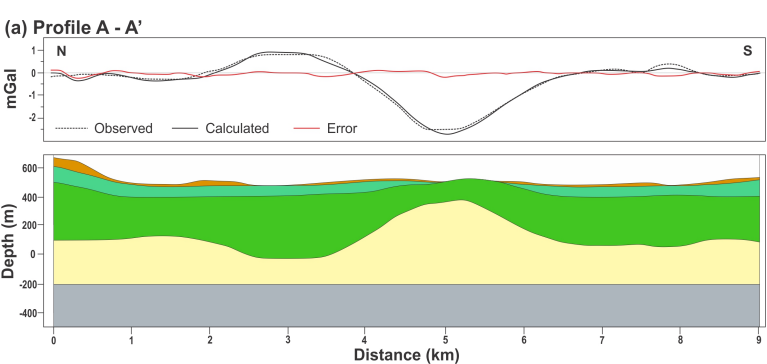

(b) Profile B - B'

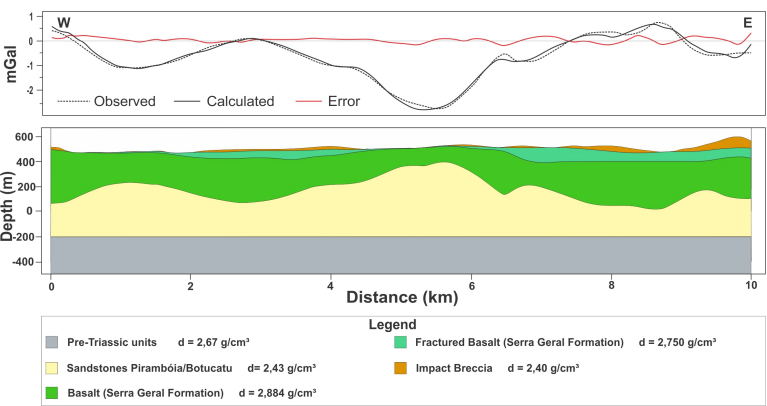

Figure 7-Vertical profiles extracted from the $3 \mathrm{D}$ gravity model of Figure 5 along (a) A-A' profile and (b) B-B' profile. Vertical exaggeration is $2 x$. The zero in the vertical scale corresponds to the EGM96 vertical datum that was used to calculate the SRTM model.

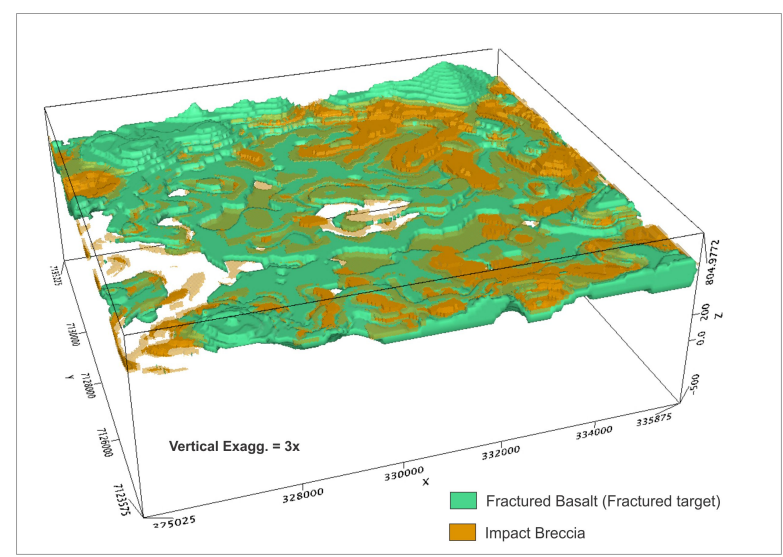

Figure 9 - Polymictic breccias (orange) and fractured basalts (green) isolated from the 3D model. Vertical exaggeration is $3 x$.

unfractured basalts reach depths of $\sim 400 \mathrm{~m}$ (Fig. 10). Based on data acquired from 13 complex impact structures in igneous and sedimentary targets, Grieve et al. (1981) propose a model to estimate the depth of excavation $\left(d_{e}\right)$ in complex structures. That value is calculated as $d_{e}=0.09-0.12 D_{e}$, where $D_{e}$ is related to the final crater diameter $D$ by $D_{e}=0.5-0.65 D$. This quantity defines a range between a minimum value (igneous targets) and a maximum value (sedimentary targets). After applying these values to Vista Alegre, we found that $d_{e}$ could vary between 420 and 750 (a) Profile C - C'

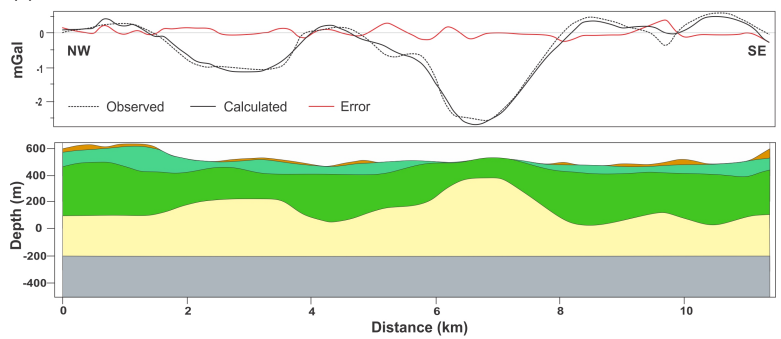

(b) Profile D - D'
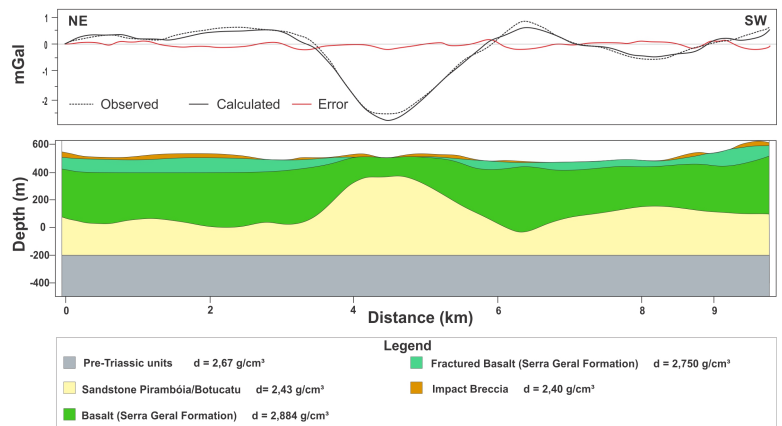

Figure 8 - Vertical profiles extracted from the 3D gravity model of Figure 5 along (a) C-C' profile and (b) D-D' profile. Vertical exaggeration is $2 x$. The zero in the vertical scale corresponds to the EGM96 vertical datum that was used to calculate the SRTM model.

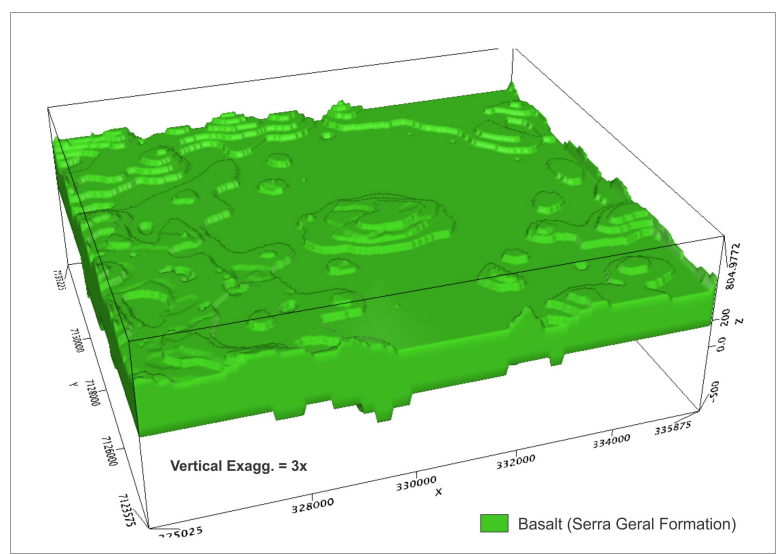

Figure $\mathbf{1 0}$ - Serra Geral basalts isolated from the 3D model. Vertical exaggeration is $3 x$.

$\mathrm{m}$. Because the impact has occurred on an igneous target, the minimum value of $420 \mathrm{~m}$ is consistent with the interpretation of our model.

\section{The central uplift of Vista Alegre}

Although there is no topographic relief that can be directly related to the presence of a central uplift, Furuie (2006) and Crósta et al. (2010) inferred it from the occurrence of sandstone clasts in the breccias and blocks of sandstones found at the 


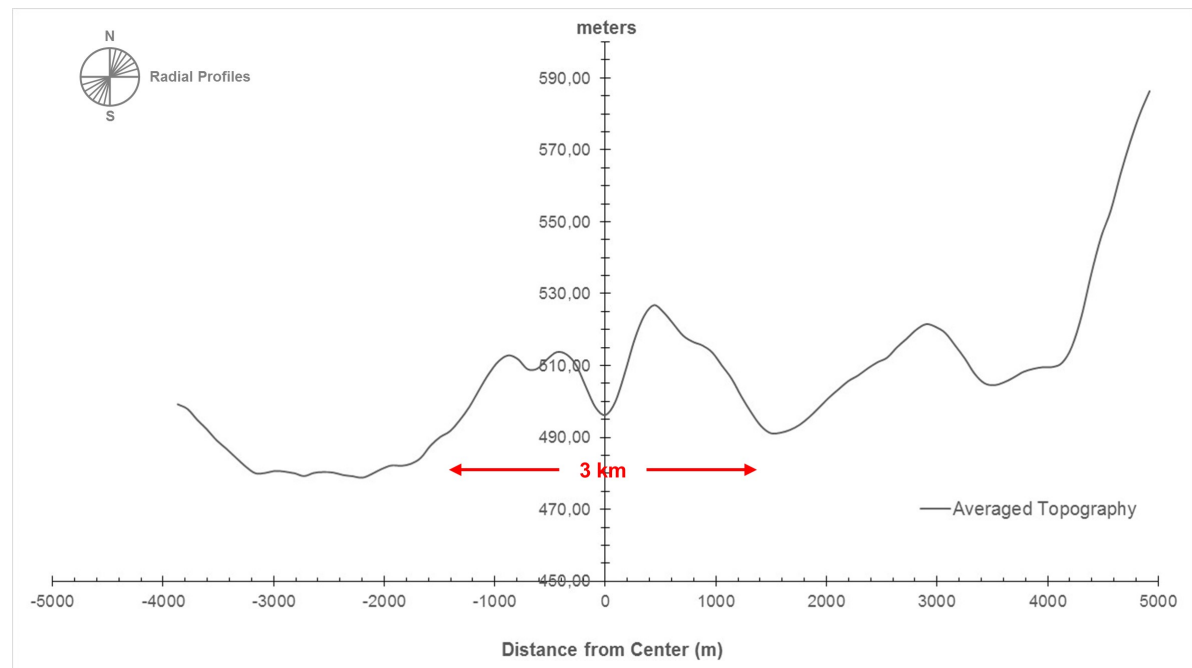

Figure 11 - Average elevation profile of the Vista Alegre impact structure. Values are based on 10 radial elevation profiles. The zero distance is at the center of the structure.

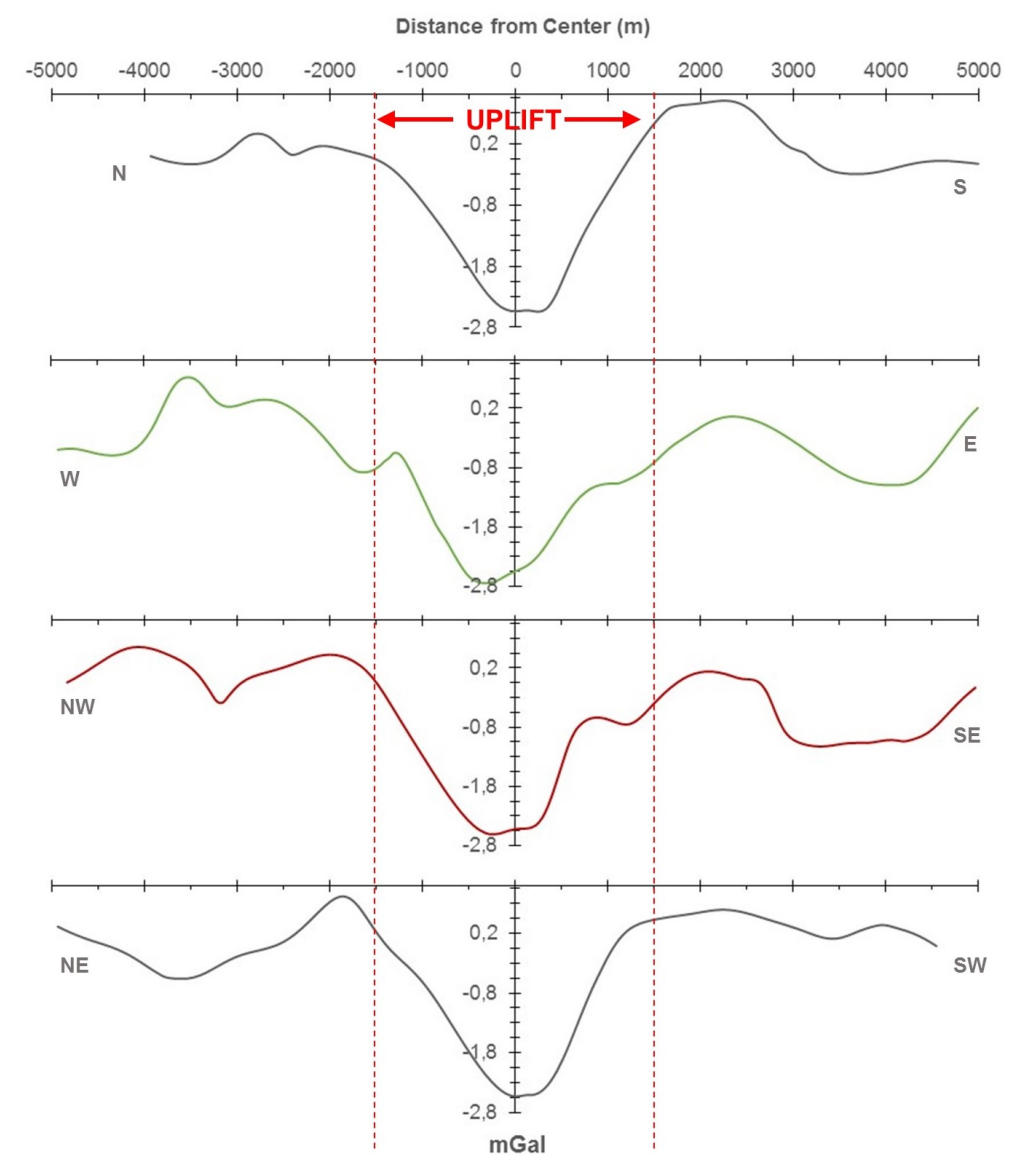

Figure 12 - Residual Bouguer anomaly profiles extracted from Figure 6A. The zero distance corresponds to the center of the central uplift. 


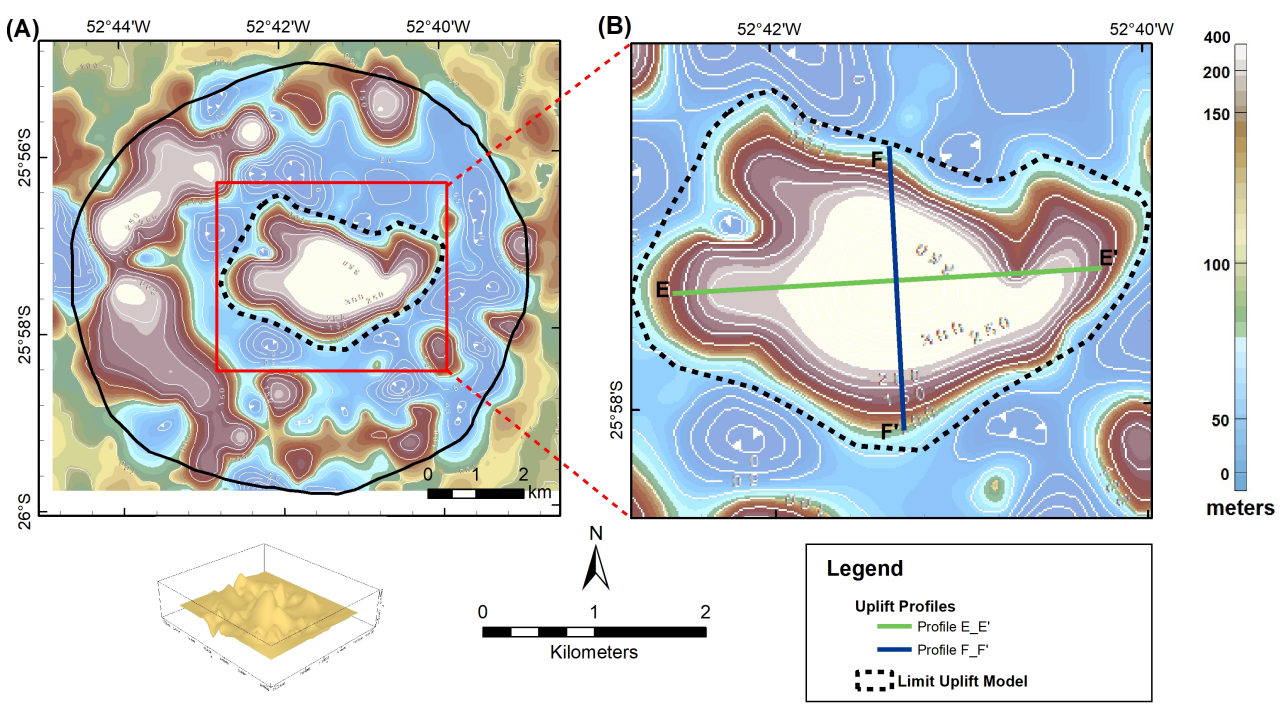

Figure 13 - (A) Depth to the top of the sandstone layer of the Vista Alegre impact structure. (B) Inset with two profiles along which residual anomalies were extracted to examine the central uplift in the model.

center of the crater. As there are no stratigraphic units with sandstones over the Serra Geral Formation in this part of the Paraná Basin, it is realistic to interpret those blocks as related to the underlying Piramboia/Botucatu sandstones. Our model depicts a stratigraphic uplift defined by the sandstone layer. Average elevations of 10 radial profiles from North to South crossing the center of the structure shows that such uplift is almost symmetric with respect to the central zero, having an elevation of $\sim 50 \mathrm{~m}$ and a diameter of $\sim 3 \mathrm{~km}$ (Fig. 11). Gravity profiles extracted from Figure $6 \mathrm{~A}$ are quite similar and a central negative anomaly of $\sim 2.5 \mathrm{mGal}$ stands out (Fig. 12). That central negative anomaly reflects a negative density contrast between sandstones and basalts. The red dashed line is symmetric with respect to the central point and represents the boundary of this $\sim 3 \mathrm{~km}$ diameter anomaly.

The uplifted block presents a nearly elliptical shape with an E-W major axis ( $\sim 3.5 \mathrm{~km}$ length) and a N-S minor axis ( $\sim 2 \mathrm{~km}$ length) (Figs. 13 and 14). Therriault et al. (1997) have established a linear fit between crater diameter $(D)$ and central uplift diameter $\left(D_{C U}\right)$, which reads as $D_{C U}=0.31 D^{1.02}$. Applying this equation to the Vista Alegre structure leads to a central uplift diameter of $\sim 3 \mathrm{~km}$, which is roughly in agreement with a mean diameter inferred from the residual Bouguer anomaly and from the elevation profile.

As shown in Figure 14, the central uplift contains both the sandstone layer and the basalt layer. The basalt layer has its lower and upper limits at approximately -200 and $450 \mathrm{~m}$, respectively, leading to a total structural uplift ( $S U$ ) of $\sim 650 \mathrm{~m}$. This amount of uplift is somewhat in agreement with that estimated from a classic empirical linear model, $S U=0.06 D^{1.1}$ (Grieve et al., 1981), where $D$ is the crater diameter, which would result in an uplift of $\sim 714 \mathrm{~m}$.

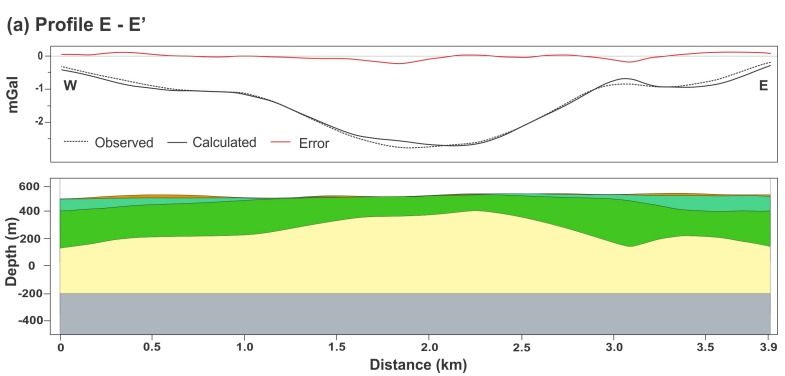

(b) Profile F - F'
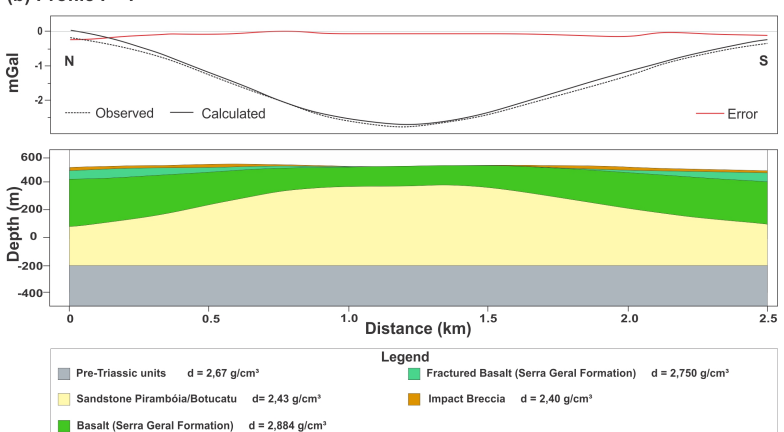

Figure 14 - Gravity model extracted at the central uplift along (a) E-E' profile and (b) F-F' profile shown in Figure 13. Vertical exaggeration is $2 x$. The zero in the vertical scale corresponds to the EGM96 vertical datum that was used to calculate the SRTM model. 


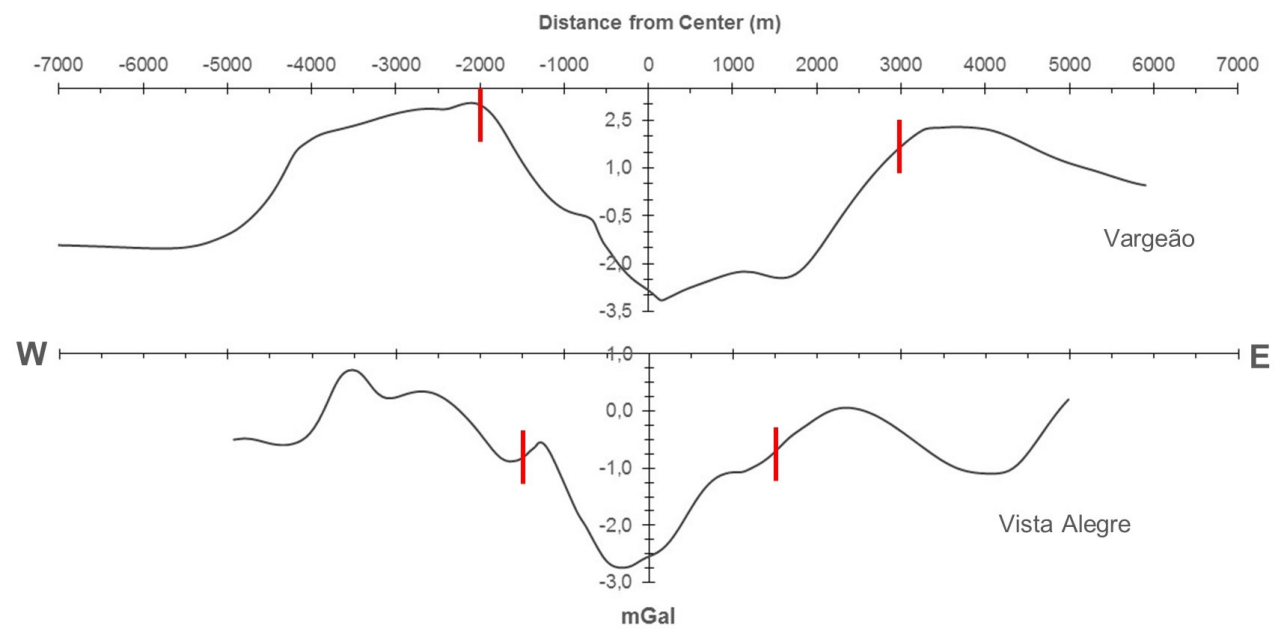

Figure 15 - Profile of the Bouguer anomaly along the E-W direction comparing both structures Vargeão (uppermost profile) and Vista Alegre (lowermost profile). Red lines point out the limits of the negative anomaly.

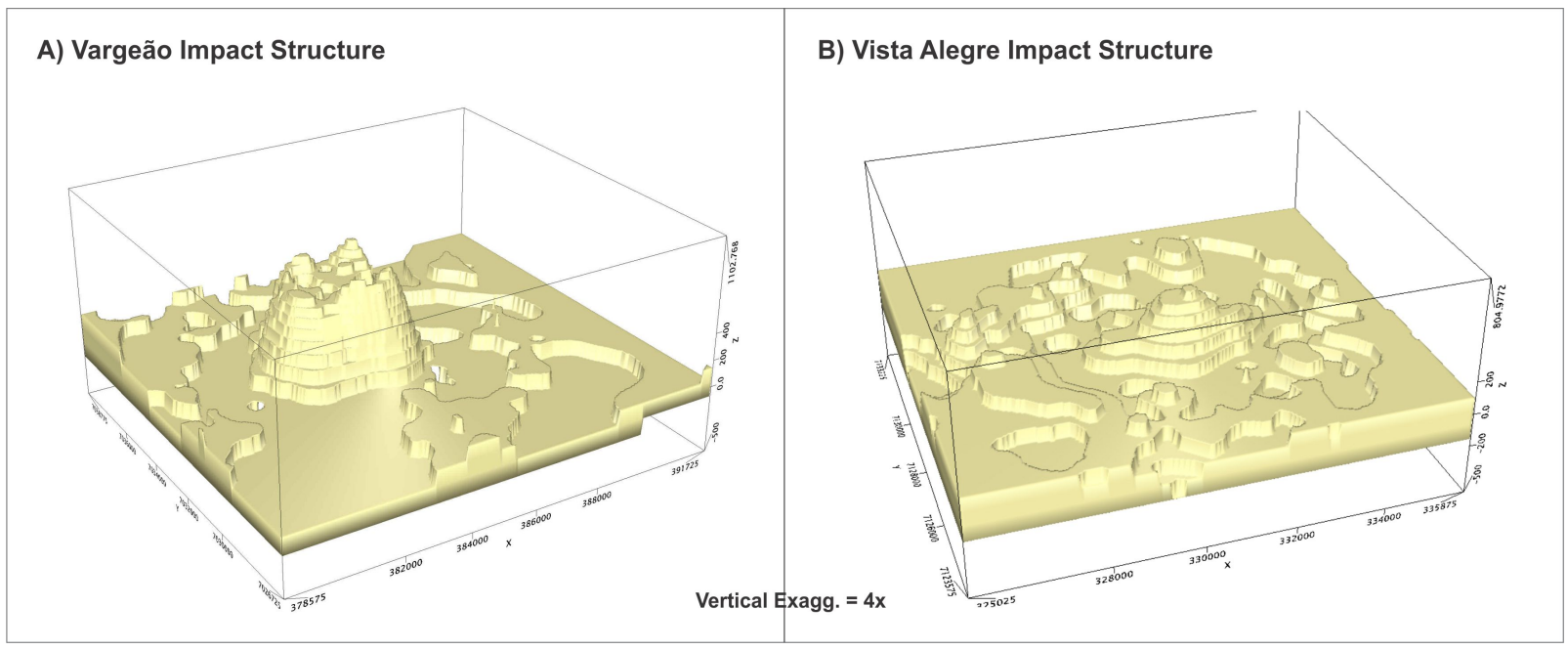

Figure 16 - 3D density models restricted to the Piramboia/Botucatu sandstones. (A) Vargeão (Ferreira et al., 2015); (B) Vista Alegre. Vertical exaggeration is 4x.

The uplifted basalt layer with an average thickness of $100 \mathrm{~m}$ above the uplifted sandstone layer (Fig. 10) explains why large outcrops of sandstones are not found in the central region of the Vista Alegre impact structure. However, a few sandstone lose blocks of the Piramboia/Botucatu Formations are exposed at the center of the crater, indicating erosion of the basaltic rocks.

Variations in elevation of the Serra Geral layer are in agreement with those expected for complex structures (Fig. 18). The only difference is that the central portion of the Vargeão model is open due the more prominent uplift of the underlying Botucatu/Piramboia sandstones.

\section{Similarities and differences between Vargeão and Vista Alegre impact structures}

Vargeão and Vista Alegre structures share some general characteristics, such as their morphology and types of rocks involved in the impact event. In both cases, sandstones of the Botucatu/Piramboia Formations were uplifted and exposed at the center, although the exposure has larger extents in Vargeão in comparison with Vista Alegre. Their central uplift diameters are different, with Vargeão structure 2 km larger than Vista Alegre. Both density models obtained from gravity inversion were similar, except for the layer of acid volcanics that occurs in Vargeão 


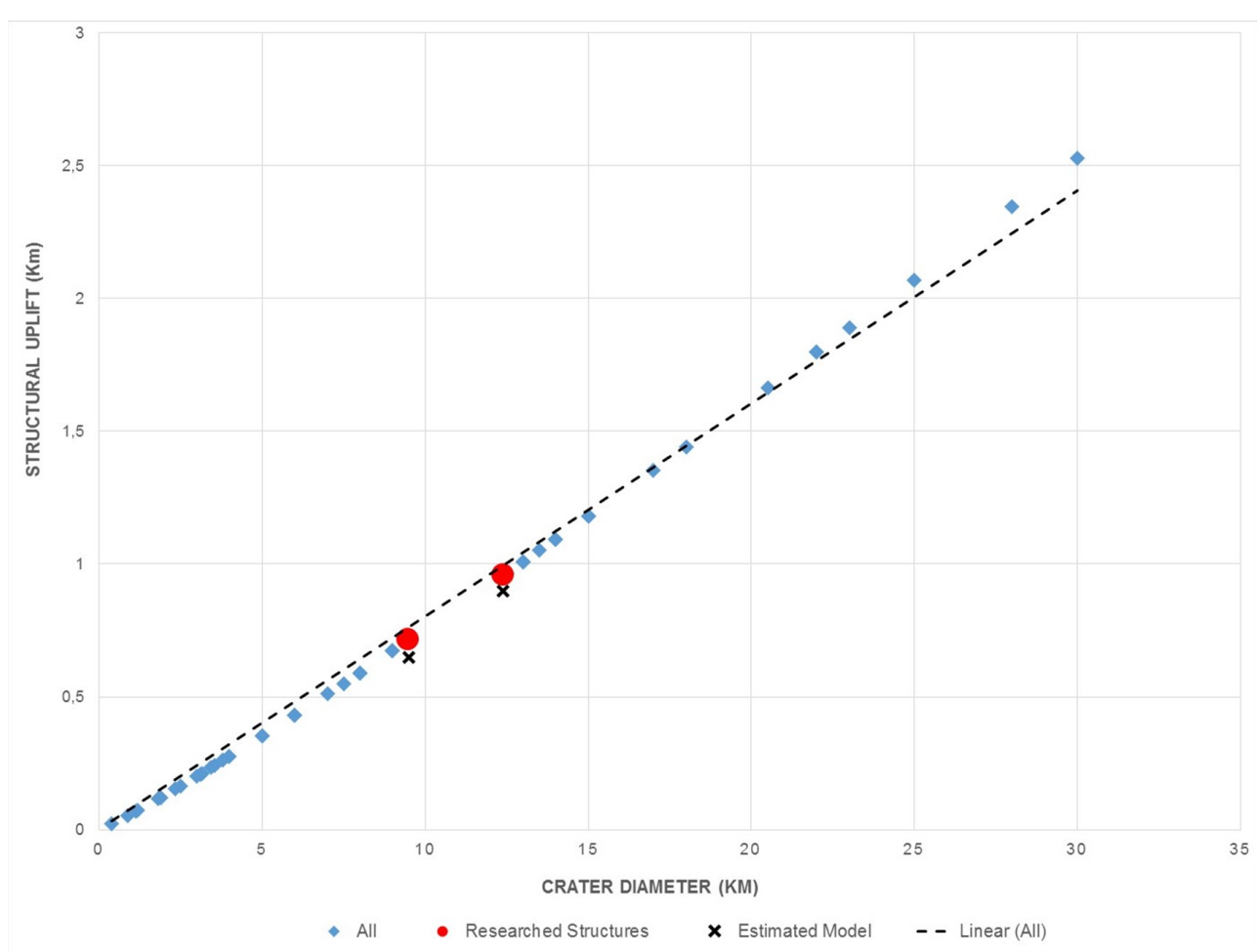

Figure 17 - Structural uplift ( $S U$ ) vs. crater diameter of 49 impact structures extracted from Pilkington \& Grieve (1992) and their fitted linear trend. Red dots indicate $S U$ theoretical values for Vargeão and Vista Alegre impact structures. Black crosses represent $S U$ values estimated from the $3 \mathrm{D}$ models for the same structures.

and not in Vista Alegre. This layer, known as Acidic Chapecó, comprises rhyodacite and rhyolite flows found at on top of the rim of Vargeão (Kazzuo-Vieira et al., 2009; Ferreira et al., 2015). The gravity signatures in both Vargeão and Vista Alegre structures show a negative anomaly in the innermost area surrounded by a ring-shaped positive anomaly. The amplitudes of the two positive anomalies are distinct and they can be directly associated with the respective diameters of the structures (Pilkington \& Grieve, 1992). In Figure 15 we compare their E-W profiles with respect to the amplitude of their anomalies and their respective limits. The central uplift diameter of Vargeão is $\sim 5 \mathrm{~km}$ whereas that of Vista Alegre is $\sim 3.0 \mathrm{~km}$, and the Vargeão anomaly is $\sim 0.5 \mathrm{mGal}$ higher than that of Vista Alegre.

The central uplift regions of Vargeão and Vista Alegre were estimated from an extracted portion of the density model (Fig. 16). By comparing the two models, we noticed that the Botucatu/Piramboia Formations present two important differences, as follows: (1) The deformation caused by the impact in Vargeão astroblem reaches the pre-Triassic layers (Fig. 16A), whereas in Vista Alegre, it is limited by the Triassic (Botucatu/Piramboia) sandstone layer (Fig. 16B); (2)
Large sandstone outcrops occur from the Botucatu/Piramboia Formations on the surface of the central uplift of Vargeão. In Vista Alegre, the uplifting has exposed only the top of Triassic Sandstones of the Botucatu/Piramboia Formations, resulting in the exposure of small blocks of sandstones as floats immersed in basalt-derived red soils.

Figure 17 presents the structural uplift $(S U)$ vs. crater diameter for the same 49 structures previously selected from the (Pilkington \& Grieve, 1992) database, plus values for Vargeão and Vista Alegre. The estimated $S U$ from our models are in agreement with the known empirical relation established in Grieve et al. (1981).

\section{CONCLUSION}

This work contributes to a better understanding of subsurface deformation undergone by target rocks due to meteoritic impacts that formed Vargeão and Vista Alegre structures. In this Part II, we propose a $3 \mathrm{D}$ density model for the Vista Alegre structure obtained from the inversion of Bouguer anomalies, which is consistent with the available geological and petrophysical information. The model depicts 3D geological structures and 


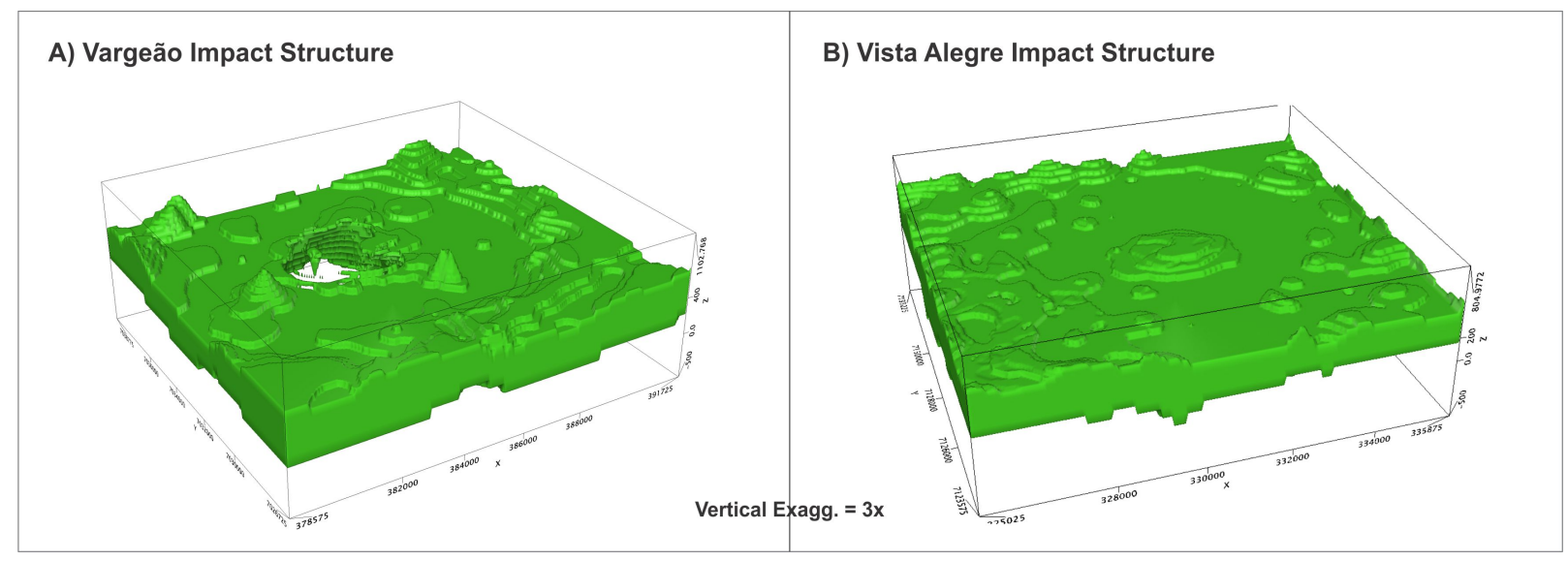

Figure 18 - 3D models of the Serra Geral Formation layer. (A) Vargeão; (B) Vista Alegre. Vertical exaggeration is 3x.

morphologies that would be expected for a complex impact structure. From 2D sections extracted from the model, a diameter of $\sim 9.5 \mathrm{~km}$ was inferred, which is consistent with a value calculated using a classical empirical model and to previous morpho-structural interpretations based on remote sensing data (Furuie, 2006). The model also indicates the presence of an uplifted sedimentary layer underneath the basalts, at the center of the structure, which we interpret as the sandstone strata of the Piramboia/Botucatu Formations. This uplift has the shape of an elliptic cone with axis lengths of $3.5 \mathrm{~km}$ and $2.5 \mathrm{~km}$. The stratigraphic uplift was estimated to $\sim 650 \mathrm{~m}$, a value that is near to the one calculated by the empirical model from Grieve et al. (1981). The similarity between Vargeão and Vista Alegre models can be explained by the occurrence of these two impact events on the same geological target along with the similar bolide diameters ( $1.25 \mathrm{~km}$ and $\sim 1 \mathrm{~km}$ for Vargeão and Vista Alegre, respectively). The fact that the Piramboia/Botucatu sandstones are better exposed in Vargeão when compared to Vista Alegre, despite the fact that the thickness of the Serra Geral volcanics is similar in both sites, can be explained by the larger diameter of Vargeão. The latter is seemingly the result of a larger impactor than the one that formed Vista Alegre.

\section{ACKNOWLEDGMENTS}

The authors thank FAPESP (Process n० 2011/08014-5) for the financial support and IG/UNICAMP for providing the geophysical equipment required for field study and the computational resources to process the geophysical data. The authors also thank IAG/USP for allowing access to their petrophysical laboratory so that our density data could be acquired. The authors are also thankful to Prof. Elder Yokoyama who provided field samples. A.P. Crósta acknowledges his research grant from CNPq (\#305911/2013-9). Special thanks go to the Copati family, who welcomed us in their lovely home at Vista Alegre village.

\section{REFERENCES}

CRÓSTA A. 2012. Estruturas de impacto e astroblemas brasileiros. In: HASUI Y, CARNEIRO CDR, ALMEIDA FFM \& BARTORELLI A (Eds.). Geologia do Brasil. São Paulo, Brazil: Ed. Beca-Ball, p. 673-708.

CRÓSTA A, KAZZUO CV \& SCHRANK A. 2004. Vista Alegre: a newly discovered impact crater in Southern Brazil. Meteoritics \& Planetary Science, 39(Suppl.). In: 67th Annual Meeting of the Meteoritical Society. Rio de Janeiro, Brazil. Abstract n. 5051.

CRÓSTA AP, KOEBERL C, FURUIE RA \& KAZZUO CV. 2010. The first description and confirmation of the Vista Alegre impact structure in the Paraná flood basalts of southern Brazil. Meteoritics \& Planetary Science, 45(2): 181-194.

CRÓSTA A, FURUIE R, SCHRANK A \& VIEIRA CK. 2013. Astroblema de Vista Alegre, PR. Impacto meteorítico em derrames vulcânicos da Formação Serra Geral, Bacia do Paraná. In: WINGE M, SCHOBBENHAUS C, SOUZA CRG, FERNANDES ACS, BERBERT-BORN M, SALLUN FILHO W \& QUEIROZ ET (Eds.). Sítios Geológicos e Paleontológicos do Brasil. SIGEP 044, Brasília. CPRM, 3: 23-36.

FERREIRA JC, LEITE EP, VASCONCELOS MAR \& CRÓSTA AP. 2015.3D Gravity Modeling of Impact Structures in Basaltic Formations in Brazil: Part I - Vargeão, Santa Catarina. Brazilian Journal of Geophysics, 33(2): 319-332.

FERREIRA JC. 2017. Modelagem gravimétrica 3D das estruturas de impacto de Vargeão-SC e Vista Alegre-PR. Master dissertation. Universidade Estadual de Campinas, SP, Brazil. 171 pp. 
FURUIE RA. 2006. Aspectos Geológicos e Feições de Impacto da Cratera de Vista Alegre, PR. Undergraduate dissertation. Universidade Estadual de Campinas. São Paulo, Brazil. 102 pp.

GRIEVE R, ROBERTSON P \& DENCE M. 1981. Constraints on the formation of ring impact structures, based on terrestrial data. In: SCHULTZ PH \& MERRILL RB (Eds.). Multi-ring basins: Formation and Evolution. Proceedings of the Lunar and Planetary Science Conference. Houston, TX. Pergamon Press. p. 37-57.

GRIEVE RA. 1987. Terrestrial impact structures. Annual Review of Earth and Planetary Sciences, 15(1): 245-270.

KAZZUO-VIEIRA C, CRÓSTA AP, GAMBOA F \& TYGEL M. 2009. Caracterização geofísica da estrutura de impacto do Domo de Vargeão, Brasil. Brazilian Journal of Geophysics, 27(3): 375-388.

MILANI EJ, FACCINI UF, SCHERER C, ARAÚJO LMD \& CUPERTINO JA. 1998. Sequences and stratigraphic hierarchy of the Paraná Basin (Ordovician to Cretaceous), southern Brazil. Boletim IG-USP, 29: 125-173.
PILKINGTON M \& GRIEVE R. 1992. The Geophysical Signature of Terrestrial Impact Craters. Reviews of Geophysics, 30: 161-181. doi: 10.1029/92RG00192.

POPOWSKI T, CONNARD G \& FRENCH R. 2006. GMSYS-3D: 3D Gravity and Magnetic Modeling for Oasis Montaj - User Guide. Corvallis, Oregon.

THERRIAULT AM, GRIEVE RAF \& REIMOLD WU. 1997. Original size of the Vredefort Structure: Implications for the geological evolution of the Witwatersrand Basin. Meteoritics \& Planetary Science, 32(1): 71-77.

TURNER S, REGELOUS M, KELLEY S, HAWKESWORTH C \& MANTOVANI M. 1994. Magmatism and continental break-up in the South Atlantic: High precision ${ }^{40} \mathrm{Ar}-{ }^{39} \mathrm{Ar}$ geochronology. Earth and Planetary Science Letters, 121: 333-348.

YOKOYAMA E. 2013. Petrologia e Magnetismo de Estruturas de Impacto da Bacia do Paraná: Reflexões sobre o Processo de Crateramento. Ph.D. thesis. Universidade de São Paulo, Instituto de Astronomia, Geofísica e Ciências Atmosféricas. São Paulo, Brazil. 259 pp.

Recebido em 1 junho, 2018 / Aceito em 18 dezembro, 2018

Received on June 1, 2018 / accepted on December 18, 2018 